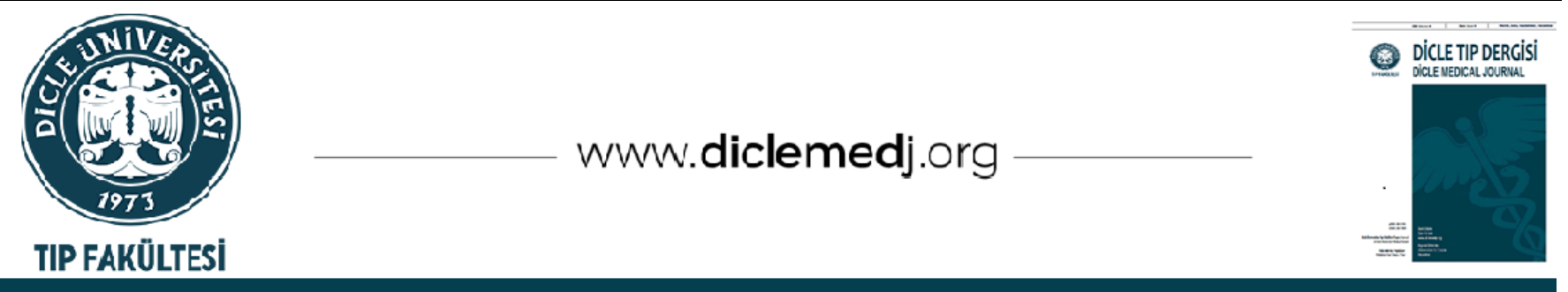

Original Article / Özgün Araştırma

\title{
The Relationship Between IgA Vasculitis and Antioxidant Activity In Children
}

\author{
Hayrettin Temel ${ }^{\mathrm{D}}$ 1, Cihangir Akgün ${ }^{\mathrm{iD}}$ 2, Mesut Okur ${ }^{\mathrm{iD}}{ }_{1}$ \\ 1 Department of Pediatrics, Istanbul Medipol University, Medical Faculty, Istanbul, Turkey \\ 2 Department of Pediatric Nephrology, Istanbul Medipol University, Medical Faculty, Istanbul, Turkey
}

Received: 15.12.2020; Revised: 20.02.2021; Accepted: 16.03.2021

\begin{abstract}
Objective: Immunoglobulin A vasculitis (IgAV) is the most common systemic vasculitis seen in children. The aim of this study is to investigate the relationship between malondialdehyde-induced oxidative stress, antioxidant system and organ involvement in IgAV patients.
\end{abstract}

Method: 32 patients and 28 healthy children were included in the study. Serum malondialdehyde, reduced glutathione, vitamin E, vitamin C, retinol, and beta-carotene levels were measured in patients (separately in both the active and remission phases) and healthy children.

Results: MDA levels were significantly higher in patients with active phase while reduced glutathione and vitamin $\mathrm{C}$ levels were markedly lower in both the active and the remission phases. Retinol and beta-carotene levels were lower in the active phase. It was found that retinol levels were significantly lower in patients with gastrointestinal system involvement compared to those without. Vitamin C levels were significantly lower in those with kidney involvement compared to those without. Also, a negative correlation was observed between retinol levels and the number of organs involved.

Conclusion: We consider that especially vitamin $\mathrm{C}$ and vitamin A may be used in the treatment of IgAV. However, whether the derangements of the oxidant/antioxidant balance in the direction of increased oxidative stress are consequences or causes of the events occurring in the active phase of IgAV are open to further investigation.

Keywords: IgA vasculitis, malondialdehyde, vitamin E, vitamin C, vitamin A

DOI: $10.5798 /$ dicletip.944308

Correspondence / Yazışma Adresi: Hayrettin Temel, Istanbul Medipol University Medical Faculty, Department of Pediatrics Istanbul, Turkey.e-mail: htemel@medipol.edu.tr 


\section{Çocuklarda IgA Vasküliti ile Antioksidan Aktivite Arasındaki İlişki}

Öz

Amaç: İmmünoglobulin A vaskülit (IgAV) çocuklarda en sık görülen sistemik vaskülittir. Bu çalışmanın amacı, IgAV hastalarında malondialdehit kaynaklı oksidatif stres, antioksidan sistem ve organ tutulumu arasındaki ilişkiyi araştırmaktır.

Yöntemler: Çalışmaya 32 hasta ve 28 sağlıklı çocuk dahil edildi. Hastalarda (hem aktif hem de remisyon fazlarında ayrı ayrı) ve sağlıklı çocuklarda serum malondialdehit, redükte glutatyon, E vitamini, C vitamini, retinol ve beta-karoten seviyeleri ölçüldü.

Bulgular: Aktif fazı olan hastalarda MDA seviyeleri önemli ölçüde daha yüksekken, redükte glutatyon ve C vitamini seviyeleri hem aktif hem de remisyon fazlarında belirgin şekilde daha düşüktü. Retinol ve beta-karoten seviyeleri aktif fazda daha düşüktü. Gastrointestinal sistem tutulumu olan hastalarda retinol düzeylerinin olmayanlara göre anlamlı derecede düşük olduğu bulundu. Böbrek tutulumu olanlarda, olmayanlara göre $C$ vitamini seviyeleri önemli ölçüde daha düşüktü. Ayrıca, retinol seviyeleri ile ilgili tutulan organ sayısı arasında negatif bir korelasyon gözlendi.

Sonuç: IgAV tedavisinde özellikle C vitamini ve A vitamininin kullanılabileceğini düşünüyoruz. Bununla birlikte, oksidan / antioksidan dengesindeki artmış oksidatif stres yönündeki düzensizliklerin, IgAV'nin aktif fazında meydana gelen olayların sonuçları mı yoksa nedenleri mi olduğu daha fazla araștırmaya açıktır.

Anahtar kelimeler: IgA vasküliti, malondialdehit, vitamin E, vitamin C, vitamin A.

\section{INTRODUCTION}

Immunoglobulin A vasculitis [IgA vasculitis (IgAV), formerly known as Henoch Schönlein purpura] is the most common form of systemic vasculitis of childhood with a reported incidence of 3-26.7 cases per $100000^{1,2}$. IgAV, characterized by the presence of immunoglobulin $\mathrm{A}$, deposits in the small vessels of skin, gastrointestinal system (GIS), joints and kidneys. Although a variety of infectious and chemical triggers are recognized, the underlying cause of IgAV remains unknown ${ }^{3}$.

Oxidative injury is initiated by free radicals and reactive oxygen metabolites (ROMs) that are generated by activated neutrophils, monocytes, macrophages, endothelial cells and mesangial cells during metabolic processes. When there is an increase in the generation of ROMs or when antioxidant defense mechanisms decrease, the shift in the oxidant/antioxidant balance cause oxidative injury that may produce derangements of cell metabolism including peroxidation of lipids resulting in cell injury and death ${ }^{4}$. Malondialdehyde (MDA), the final product of lipid peroxidation induced by ROMs, leads to crosslinking in lipids, proteins and nucleic acids, and is considered an important marker of oxidative stress $^{4,5}$.

Antioxidants reduce oxidative damage by inhibiting the activity or expression of free radical-producing enzymes either directly or indirectly by reacting with free radicals or by increasing the activity or expression of intracellular antioxidant enzymes ${ }^{6}$. Reduced glutathione (GSH) is the predominant intracellular antioxidant in many organisms. GSH protects cells against a wide variety of free radicals such as reactive oxygen species, lipid peroxides, xenobiotic toxins, and heavy metals ${ }^{7}$. Vitamin E (alpha-tocopherol), a natural antioxidant, neutralizes free radicals and protects the cell membrane against free oxygen radicals. It also improves the functions of other antioxidants by preventing lipid peroxidation ${ }^{8}$. Vitamin $\mathrm{C}$ is a powerful antioxidant that protects cell membranes from damage by eliminating the effects of radicals that initiate lipid peroxidation'. Vitamin A, which is stored mainly in the liver as retinol, is the name given to a group of fat-soluble retinoids and carotenoids ${ }^{10}$. Beta-Carotene is a strong antioxidant that serves as a scavenger of singlet oxygen. It is also a provitamin A as it can be 
converted into retinol ${ }^{11}$. Because of the close metabolic relationship between beta-carotene and retinol, it is important to evaluate their physiological effects together ${ }^{12}$.

Oxidative injury is implicated in the pathogenesis of various inflammatory, metabolic and toxic insults and ischemic reperfusion injury 4 . Several experimental studies on oxidative injury in glomerular diseases and vasculitis have been carried out, but few clinical studies have been performed ${ }^{13,14}$.

In this study, the role of oxidative stress in the pathogenesis of IgAV and its relationship with organ and oxidant/antioxidant involvement were investigated on the basis of clinical and laboratory parameters.

\section{METHODS}

This study was conducted prospectively with the approval of the local ethics committee (Date: 24/11/2009 Decision number: 2009/05). Thirtytwo of 38 patients diagnosed with IgAV and 28 healthy children who applied to the outpatient clinic as a control group were included in the study. Six patients with IgAV were excluded from the study because they could not be followed up. All of the patients were acute cases with no history of chronic disease, and none of the patients had undergone glucocorticoid and/or antioxidant treatment before their admission.

Diagnosis of IgAV was made according to the American College of Rheumatology diagnostic criteria $^{15}$. Patient population with IgAV consisted of $17(53 \%)$ male and 15 (47\%) female patients with an overall mean age of $9.53 \pm 2.9$ (range, 3 to 16) years. Control group was comprised of 17 (61\%) male and 11 (39\%) female children with an overall mean age of $9.64 \pm 3.12$ (range, 4 to 16 ) years. Skin involvement was found in 32 (100\%), joint involvement in 24 (75\%), GIS involvement in 19 (59\%), and renal involvement in 8 (25\%) patients with IgAV. The coexistence of skin, GIS and kidney involvement was found in 7 cases $(22 \%)$, and the coexistence of skin, joint and kidney involvement was seen in 7 cases (22\%).
Antihistamines (hydroxyzine) were administered to those with only skin involvement, non-steroidal anti-inflammatory drugs (naproxen sodium) to those with joint involvement, oral steroids (prednisolone) to those with GIS involvement, and parenteral steroids to those with renal involvement. The patients with IgAV were evaluated in two separate periods, referred to as active phase and remission phase. The stage in which clinical symptoms started at least one week prior to and continued at the time of admission was considered to be the active phase, while the period one month after the complete recovery of clinical and laboratory findings was considered to be the remission phase.

Physical examination findings and demographic data of the patients were performed in detail. Complete blood count, erythrocyte sedimentation rate (ESR), C-reactive protein (CRP), total protein, albumin, and IgA values were obtained from both the patients and the control group. All patients with fecal occult blood were investigated for GIS involvement. Protein (mg/dL) levels were measured in 24-hour urine samples collected from patients with proteinuria detected during urinalysis. In addition, venous blood samples were taken from the patients during both the active and remission phase and the control group to measure the levels of GSH, MDA, alphatocopherol, vitamin $\mathrm{C}$, retinol and-carotene.

\section{Statistical Analysis}

A normal distribution of the quantitative data was analyzed using the Kolmogorov-Smirnov test. Parametric tests (Independent-samples t-test and posthoc Tamhanes'T2 test) were applied to the data of normal distribution, and non-parametric tests (Mann-Whiney U-test and Kruskal-Wallis Test) were applied to the data of questionably normal distribution. To calculate correlation coefficients Pearson's $r$ and Kendall's tau b were used. The distribution of categorical variables in both groups was compared using Pearson chisquare, Continuity Correction, and Fisher's exact tests. All differences associated with a chance probability of 0.05 or less were considered to be statistically significant. 


\section{RESULTS}

The mean white blood cell values were significantly higher in the active phase of the patients compared to the healthy children $(\mathrm{p}<0.001)$. Platelet count was predominantly higher in both the active and remission phase compared to the control group $(\mathrm{p}<0.001)$. Comparisons of complete blood cell values between groups are found in Table 1. Mean total protein and albumin level were statistically significantly lower in the active phase when compared with healthy children $(\mathrm{p}<0.001)$. The CRP and ESR values in active phase were significantly higher than those of the remission phase $(\mathrm{p}<0.05)$, but this difference was more significant when compared with healthy children $(\mathrm{p}<0.001)$. IgA was significantly higher in patients with active phase IgAV compared to the control group $(\mathrm{p}<0.001)$ (Table 2).

Table I: Intergroup comparisons of complete blood cell counts.

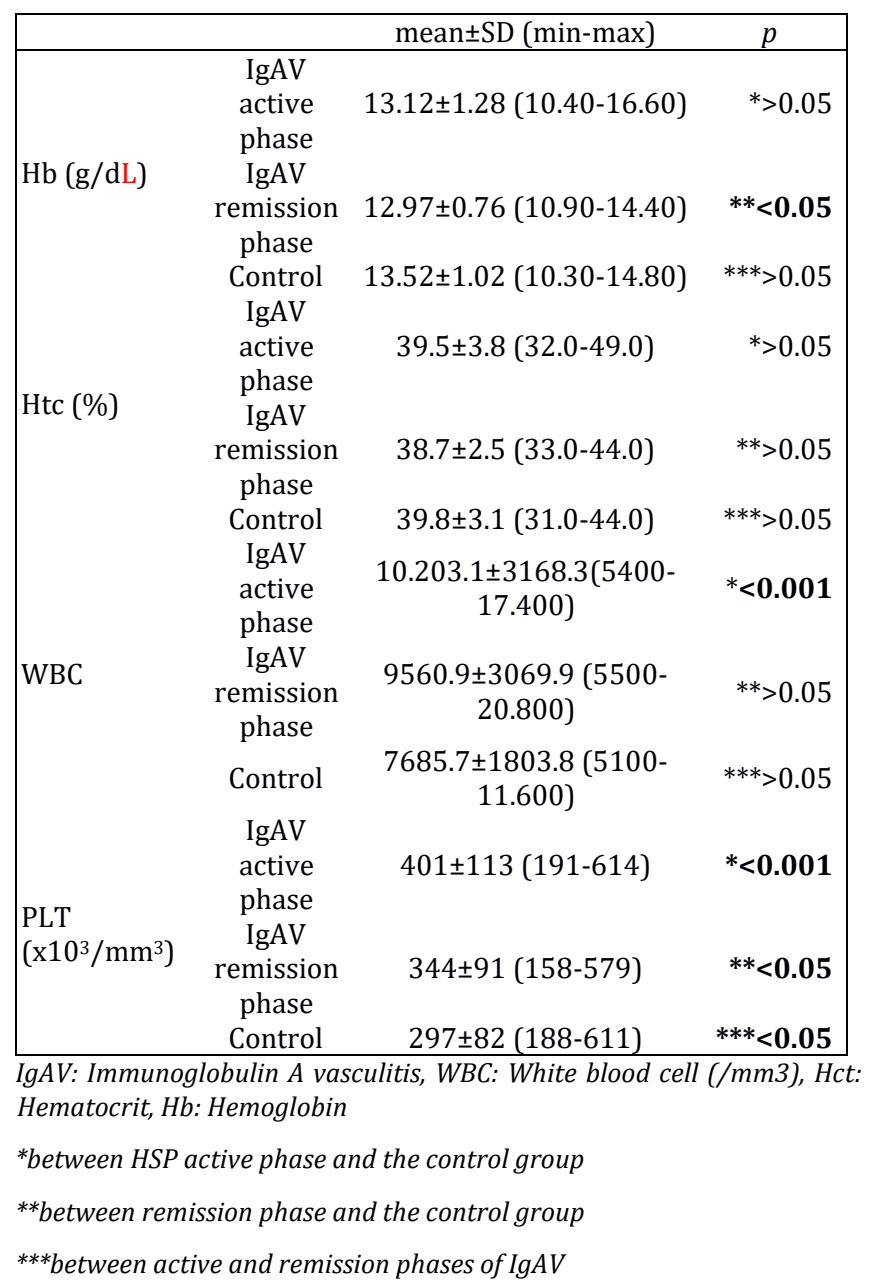

Table II: Intergroup comparisons of biochemical parameters, erythrocyte sedimentation rate, C-reactive protein, and IgA levels.

\begin{tabular}{|c|c|c|c|}
\hline & & mean $\pm S D(\min -m a x)$ & $p$ \\
\hline \multirow{3}{*}{$\mathrm{TP}(\mathrm{g} / \mathrm{dL})$} & $\begin{array}{l}\text { IgAV active } \\
\text { phase } \\
\text { IgAV }\end{array}$ & $6.93 \pm 0.71(5.4-8.7)$ & $*<0.001$ \\
\hline & $\begin{array}{l}\text { remission } \\
\text { phase }\end{array}$ & $7.21 \pm 0.51(6.4-8.6)$ & $* *<0.05$ \\
\hline & Control & $7.53 \pm 0.49(6.89-8.58)$ & $* * *<0.05$ \\
\hline \multirow{3}{*}{$\operatorname{Alb}(\mathrm{g} / \mathrm{dL})$} & $\begin{array}{l}\text { IgAV active } \\
\text { phase } \\
\text { IgAV }\end{array}$ & $4.04 \pm 0.31(3.5-4.8)$ & $*_{<0.001}$ \\
\hline & $\begin{array}{l}\text { remission } \\
\text { phase }\end{array}$ & $4.43 \pm 0.33(3.9-5.1)$ & $* *<0.001$ \\
\hline & Control & $4.94 \pm 0.26(4.46-5.33)$ & $* * *<0.001$ \\
\hline \multirow{3}{*}{$\begin{array}{l}\text { ESR } \\
(\mathrm{mm} / \mathrm{hr})\end{array}$} & $\begin{array}{l}\text { IgAV active } \\
\text { phase }\end{array}$ & $19.9 \pm 10.8(10-47)$ & $*<0.001$ \\
\hline & $\begin{array}{l}\text { IgAV } \\
\text { remission } \\
\text { phase }\end{array}$ & $13.3 \pm 8.6(4-42)$ & ${ }^{* *}>0.05$ \\
\hline & Control & $10.2 \pm 5.3(3-20)$ & $* * *<0.05$ \\
\hline \multirow{3}{*}{$\begin{array}{l}\text { CRP } \\
\text { (mg/L) }\end{array}$} & $\begin{array}{l}\text { IgAV active } \\
\text { phase } \\
\text { IgAV }\end{array}$ & $14.33 \pm 17.71(2.97-96)$ & $*<0.05$ \\
\hline & $\begin{array}{l}\text { remission } \\
\text { phase }\end{array}$ & $3.71 \pm 1.84(2.8-13)$ & $*^{* *}>0.05$ \\
\hline & Control & $3.64 \pm 0.91(3.1-6.63)$ & $* * *<0.05$ \\
\hline \multirow{3}{*}{$\operatorname{IgA}(\mathrm{g} / \mathrm{L})$} & $\begin{array}{l}\text { IgAV active } \\
\text { phase } \\
\text { IgAV }\end{array}$ & $318 \pm 112(135-672)$ & $*<0.05$ \\
\hline & $\begin{array}{l}\text { remission } \\
\text { phase }\end{array}$ & $244 \pm 68(1.5-390)$ & $* *>0.05$ \\
\hline & Control & $159 \pm 56(0.86-322)$ & $* * *>0.05$ \\
\hline
\end{tabular}

IgAV: Immunoglobulin A vasculitis, TP: Total protein, Alb: Albumin, ESR: Erythrocyte sedimentation rate; CRP: C-reactive protein

*between HSP active phase and the control group

** between remission phase and the control group

***between active and remission phases of IgAV

MDA levels were significantly higher in patients with IgAV in the active phase compared to the control group $(\mathrm{p}<0.001)$. GSH levels in the active phase were significantly lower relative to healthy children and the patients in remission phase $(p<0.001)$. Vitamin C levels were significantly lower in the active phase compared to the healthy children $(\mathrm{p}<0.001)$. There was no difference in this regard for other antioxidants. Comparisons between antioxidants and active phase, remission phase, and the healthy control group are shown in Table 3. 
Table III: Intergroup comparisons of malondialdehyde, GSH, vitamin C, beta-carotene, retinol and vitamin E levels.

\begin{tabular}{|c|c|c|c|}
\hline & & mean $\pm S D(\min -\max )$ & $p$ \\
\hline \multirow{3}{*}{$\begin{array}{l}\text { MDA } \\
(\mathrm{nmol} / \mathrm{mL})\end{array}$} & $\begin{array}{l}\text { IgAV active } \\
\text { phase }\end{array}$ & $3.25 \pm 2.2(1.23-9.45)$ & $*<0.001$ \\
\hline & $\begin{array}{l}\text { IgAV } \\
\text { remission } \\
\text { phase }\end{array}$ & $1.86 \pm 1.13(0.77-6.67)$ & $* *>0.05$ \\
\hline & Control & $1.48 \pm 0.56(0.25-2.65)$ & $* * *<0.05$ \\
\hline \multirow{3}{*}{$\begin{array}{l}\text { GSH } \\
(\mathrm{mg} / \mathrm{dL})\end{array}$} & $\begin{array}{l}\text { IgAV active } \\
\text { phase }\end{array}$ & $24.2 \pm 4.22(18.88-36.16)$ & $*<0.001$ \\
\hline & $\begin{array}{l}\text { IgAV } \\
\text { remission } \\
\text { phase }\end{array}$ & $32.01 \pm 7.07(19.84-52.48)$ & $* *>0.05$ \\
\hline & Control & $34.56 \pm 5.49(26.88-53.12)$ & $* * *<0.001$ \\
\hline \multirow{3}{*}{$\begin{array}{l}\text { Vitamin C } \\
(\mathrm{mg} / \mathrm{dL})\end{array}$} & $\begin{array}{l}\text { IgAV active } \\
\text { phase }\end{array}$ & $1.59 \pm 0.22(1.3-2.14)$ & $*<0.001$ \\
\hline & $\begin{array}{l}\text { IgAV } \\
\text { remission } \\
\text { phase }\end{array}$ & $1.61 \pm 0.25(1.18-2.17)$ & $* *<0.001$ \\
\hline & Control & $1.98 \pm 0.3(1.31-2.51)$ & $* * *>0.05$ \\
\hline \multirow{3}{*}{$\begin{array}{l}\text { Beta- } \\
\text { carotene } \\
(\mu \mathrm{g} / \mathrm{dL})\end{array}$} & $\begin{array}{l}\text { IgAV active } \\
\text { phase } \\
\text { IgAV }\end{array}$ & $19.46 \pm 3.82(8.99-24.41)$ & $*>0.05$ \\
\hline & $\begin{array}{l}\text { remission } \\
\text { phase }\end{array}$ & $20.8 \pm 3.7(13.95-30.62)$ & $* *>0.05$ \\
\hline & Control & $21.39 \pm 3.4(16.27-28.29)$ & $* * *>0.05$ \\
\hline \multirow{3}{*}{$\begin{array}{l}\text { Retinol } \\
(\mu \mathrm{g} / \mathrm{dL})\end{array}$} & $\begin{array}{l}\text { IgAV active } \\
\text { phase }\end{array}$ & $35.69 \pm 7.76(12.22-49.5)$ & $*>0.05$ \\
\hline & $\begin{array}{l}\text { remission } \\
\text { phase }\end{array}$ & $35.76 \pm 5.47(24.52-55.52)$ & $* *>0.05$ \\
\hline & Control & $36.82 \pm 6.34(28.52-52.1)$ & $* * *>0.05$ \\
\hline \multirow{3}{*}{$\begin{array}{l}\text { Vitamin E } \\
\text { (mg/dL) }\end{array}$} & $\begin{array}{l}\text { IgAV active } \\
\text { phase }\end{array}$ & $0.89 \pm 0.32(0.12-1.25)$ & $*>0.05$ \\
\hline & $\begin{array}{l}\text { IgAV } \\
\text { remission } \\
\text { phase }\end{array}$ & $0.9 \pm 0.17(0.53-1.4)$ & $* *>0.05$ \\
\hline & Control & $0.91 \pm 0.11(0.76-1.24)$ & $* * *>0.05$ \\
\hline
\end{tabular}

GSH: reduced glutathione, IgAV: Immunoglobulin A vasculitis, MDA: Malondialdehyde

*between HSP active phase and the control group

**between remission phase and the control group

***between active and remission phases of IgAV

Mean retinol levels were significantly lower in patients with GIS involvement than in patients without GIS involvement ( $p$ <0.05). Mean vitamin $\mathrm{C}$ levels in patients with renal involvement were significantly lower than patients without renal involvement $(p<0.05)$.
No relationship was found between other antioxidants and organ involvement. The relationship between antioxidants levels and organ involvement are shown in Table 4. A negative correlation was found between retinol levels and the number of organs involved ( $\mathrm{r}=-$ $0.403, \mathrm{p}<0.05$ ).

Table IV: The comparison of oxidant/antioxidant levels (mean \pm standard deviations) according to organ involvement

\begin{tabular}{|c|c|c|c|c|}
\hline & $\begin{array}{l}\text { Joint } \\
\text { (n: 24) }\end{array}$ & $\begin{array}{c}\text { GIS } \\
(n: 19)\end{array}$ & $\begin{array}{l}\text { Renal } \\
\text { (n: 8) }\end{array}$ & $p$ \\
\hline GSH (mg/dL) & $23.79 \pm 3.59$ & $3.43 \pm 2.13$ & $\begin{array}{c}2.84 \pm \\
0.86\end{array}$ & $\begin{array}{r}> \\
0.05\end{array}$ \\
\hline Vitamin C (mg/dL) & $1.6 \pm 0.22$ & $1.64 \pm 0.23$ & $\begin{array}{c}1.47 \pm \\
0.15\end{array}$ & $\begin{array}{r}< \\
0.05^{*}\end{array}$ \\
\hline $\begin{array}{l}\text { Beta-caroten } \\
(\mu \mathrm{g} / \mathrm{dL})\end{array}$ & $20.15 \pm 3.59$ & $18.89 \pm 4.29$ & $\begin{array}{c}20.6 \pm \\
2.94\end{array}$ & $\begin{array}{r}> \\
0.05\end{array}$ \\
\hline Retinol ( $\mu \mathrm{g} / \mathrm{dL})$ & $35.19 \pm 6.29$ & $32.68 \pm 7.98$ & $\begin{array}{c}34.2 \pm \\
6.26\end{array}$ & $0.05^{* *}$ \\
\hline Vitamin E (mg/dL) & $0.86 \pm 0.36$ & $0.86 \pm 0.36$ & $0.9 \pm 0.37$ & $\begin{array}{r}> \\
0.05\end{array}$ \\
\hline
\end{tabular}

When the patients are evaluated in terms of treatment; Antihistamine treatment was given to $10(31 \%)$ patients, non-steroidal antiinflammatory drug treatment in addition to antihistamine treatment in 14 (44\%) patients, and steroid therapy to 8 (25\%) patients. All patients were treated during the follow-up period.

\section{DISCUSSION}

Laboratory values did reveal a unique finding that can be used to diagnose the disease. However, laboratory findings can be useful in the differentiation of IgAV from other diseases, to predict prognosis and to formulate appropriate treatment. According to the definition of the disease, it should be shown that there is no thrombocytopenia. It is reported that the platelet count may be normal or high ${ }^{4,16}$. Ece et al. and Akça et al. detected thrombocytosis in 
$32.5 \%$ and $28.8 \%$ of their patients, respectively ${ }^{17,18}$. In our study, the platelet count was higher in the active phase compared to both the remission phase and the control group. This was considered to be a result of inflammation. A slight increase in leucocyte levels and acute phase reactants may also be seen ${ }^{4}$. Peru et al. and also Trapani et al. reported leukocytosis in $47 \%$ and $21 \%$ of their cases respectively ${ }^{19,20}$. ESR has been reported to vary in IgAV. Increased ESR levels have been reported by Farley et al. (33\%), Trapani et al. (57\%) in indicated percentages of their patients ${ }^{20-21}$. In studies examining CRP levels, Koçak et al. and also Cakiter et al. detected higher CRP levels in $26.4 \%$ and $46.7 \%$ of their patients, respectively ${ }^{22,23}$. In our study, both the CRP and ESR levels were significantly higher in the active phase compared to healthy children. However, this increase did not continue during the remission period. A significant increase in ESR, CRP, and leukocyte levels were seen in the active phase compared to healthy children, therefore these values were considered a marker of the acute-phase response.

Serum IgA levels have been reported to be elevated in 18.5 to 42.9 percent of patients with IgAV19,24. In our study, we found an increased serum IgA level in $18 \%$ of the patients.

In this study, we investigated whether there is a difference between oxidant/antioxidant levels in IgAV patients and gained insight into the role of oxidative stress in the pathogenesis of the disease to help the emergence of new treatment methods. In a healthy individual, the oxidant levels and the power of antioxidants to neutralize them is in balance. Oxidative stress, which is currently being investigated, is thought to be a possible component in the pathogenesis of various diseases including IgAV.

In a study, markedly elevated levels of MDA and lower levels of vitamin $\mathrm{E}$ were found in patients with active IgAV compared to those in the remission phase 25 . In a study of 27 IgAV patients, superoxide dismutase and glutathione peroxidase levels were found to be lower while the MDA levels were found to be significantly higher in the active phase when compared with the remission phase and control group ${ }^{26}$. In another study including 16 IgAV patients, predominantly higher MDA levels were seen in patients with active phase when compared with those in the remission phase and control group ${ }^{14}$. As an indicator of oxidative stress in our study, serum MDA levels were significantly higher in the active phase of the disease compared to the remission and control groups, and were consistent with the other studies. This situation supports the view that oxidative stress may play a significant role in the pathogenesis of IgAV.

Levels of GSH, which we considered as an indicator of the antioxidant system, were markedly lower in the active phase when compared with those of the healthy children and the remission phase. Vitamin $C$ levels were found to be significantly lower in the active and remission phases when compared with healthy children, although no major difference was found between the active and remission phases. Beta-carotene levels were lower in the active phase relative to the control group, but not significantly different from those detected in the remission phase. Similar to beta-carotene, retinol levels were lower in the active phase relative to the remission phase and the control group, but this difference was not statistically significant. There was no significant difference between the groups in terms of vitamin E. Our findings are similar to other studies in the literature showing that antioxidants are low in the active phase of the disease in IgAV patients ${ }^{27,28}$.

Various studies have explored the relationship between oxidative stress and organ involvement in IgAV pathogenesis. In a study, 
when evaluated according to renal involvement, a significant difference was found in terms of MDA levels. However, no significant difference was seen in MDA levels between those with and without GIS involvement ${ }^{14}$. In another study of 29 IgAV patients and 30 healthy children, significantly higher MDA levels were detected in patients during the active phase compared to the remission phase and control group ${ }^{27}$. The authors found that when evaluated according to organ involvement, the oxidant/antioxidant parameters of patients with or without joint, GIS and renal involvement were similar ${ }^{27}$. In a more recent study, there was no significant difference between oxidant/antioxidant parameters of the patients with or without organ involvement ${ }^{28}$. In our study, vitamin $C$ levels in patients with renal involvement and retinol levels in patients with GIS involvement were found to be significantly lower. Previous studies and results of our study indicate that further research are needed to determine the relationship between oxidant/antioxidant parameters and organ involvement.

\section{CONCLUSION}

It was determined that retinol levels were significantly lower in those with GIS involvement than those without GIS involvement, and vitamin C levels were significantly lower in those with renal involvement. There was no significant difference in terms of other oxidant/antioxidant parameters. There was a negative correlation between retinol levels and the number of organs involved $(\mathrm{r}=-0.403, \mathrm{p}<0.05)$. We think that especially vitamin $C$ and retinol can be used in the treatment of IgAV. However, whether the irregularities in the oxidant/antioxidant balance in the direction of the increased oxidative stress are the result or cause of the events occurring in the active phase of the disease is open for further investigation. In addition to the results of this study, multi-center studies are needed in larger patient groups.
Congress Oral Presentation: " This study was presented as an Oral Presentation on '6th International Congress of Health Sciences and Family Medicine 2021' on 16-18 April 2021.

Ethics Committee Approval: This study was conducted prospectively with the approval of the local ethics committee (Date: 24/11/2009 Decision number: 2009/05).

Declaration of Conflicting Interests: The authors declare that they have no conflict of interest.

Financial Disclosure: No financial support was received.

\section{REFERENCES}

1. Jennette JC, Falk RJ, Bacon PA, et al. 2012 Revised International Chapel Hill Consensus Conference Nomenclature of Vasculitides. Arthritis Rheum. 2013; 65: 1-11.

2. Piram M, Mahr A. Epidemiology of immunoglobulin A vasculitis (Henoch-Schönlein): current state of knowledge. Curr Opin Rheumatol. 2013 ;25: 171-8.

3. Rigante D, Castellazzi L, Bosco A, et al. Is there a crossroad between infections, genetics, and HenochSchönlein purpura?. Autoimmun Rev. 2013; 12: 1016-21.

4. Kattoor AJ, Pothineni NVK, Palagiri D, et al. Oxidative Stress in Atherosclerosis. Curr Atheroscler Rep. 2017; 19: 42.

5. Dalbaşı E, Gedik E, Tüzün A, Obay B. Correlation of Malondialdehyde and Antioxidant Enzyme Levels with Peritonitis Severity in Patients with Generalized Peritonitis. Dicle Med Journal. 2020; 47: 293-03.

6. Lü JM, Lin PH, Yao Q, Chen C. Chemical and molecular mechanisms of antioxidants: experimental approaches and model systems. J Cell Mol Med. 2010; 14: 840-60.

7. Narayanankutty A, Job JT, Narayanankutty V. Glutathione, an Antioxidant Tripeptide: Dual Roles in Carcinogenesis and Chemoprevention. Curr Protein Pept Sci. 2019; 20: 907-17. 
8. Engin KN. Alpha-tocopherol: looking beyond an antioxidant. Mol Vis. 2009; 15: 855-60.

10. Sies H, Stahl W. Vitamins E and C, beta-carotene, and other carotenoids as antioxidants. Am J Clin Nutr. 1995; 62: 1315-21.

11. P. Padmanabhan, A. Cheema, G. Paliyath, Solanaceous Fruits Including Tomato, Eggplant, and Peppers. Encyclopedia of Food and Health, 1st edn. Oxford: Academic Press, 2016; 24-32.

12. Vance TM, Su J, Fontham ET, et al. Dietary antioxidants and prostate cancer: a review. Nutr Cancer. 2013; 65: 793-801.

13. Túri S, Németh I, Torkos A, et al. Oxidative stress and antioxidant defense mechanism in glomerular diseases. Free Radic Biol Med. 1997; 22: 161-68.

14. Demircin G, Oner A, Unver Y, et al. Erythrocyte superoxide dismutase activity and plasma malondialdehyde levels in children with Henoch Schönlein purpura. Acta Paediatr. 1998; 87: 848-52.

15. Mills JA, Michel BA, Bloch DA, et al. The American College of Rheumatology 1990 criteria for the classification of Henoch-Schönlein purpura. Arthritis Rheum. 1990; 33: 1114-121.

16. Cassidy JT, Petty RE: Textbook of Pediatric Rheumatology: Leucocytoclastic vasculitis, 5th edn. Philadelphia, Elsevier Saunders, 2005; 496-512.

17. Ece A, Yolbaș İ, Balık H, et al. Henoch-Schönlein purpura in childhood: Review of 214 patients, J Clin Exp Invest. 2012; 3: 91-5.

18. Akça Ü, Akça G, Nalcacıoğlu H, et al. Evaluation of epidemiological, clinical and laboratory findings in Henoch Schönlein purpura. Turkish Journal of Family Practice. 2020; 24: 87-94.

19. Peru H, Soylemezoglu O, Bakkaloglu SA, et al. Henoch Schonlein purpura in childhood: clinical analysis of 254 cases over a 3-year period. Clin Rheumatol. 2008; 27:1087-92.

20. Trapani S, Micheli A, Grisolia F, et al. Henoch Schonlein purpura in childhood: epidemiological and clinical analysis of 150 cases over a 5-year period and review of literature. Semin Arthritis Rheum. 2005; 35: 143-53.
9. Berger MM, Oudemans-van Straaten HM. Vitamin C supplementation in the critically ill patient. Curr Opin Clin Nutr Metab Care. 2015; 18: 193-201.

21. Farley TA, Gillespie S, Rasoulpour M, et al. Epidemiology of a cluster of Henoch-Schönlein purpura. Am J Dis Child. 1989; 143: 798-803.

22. Koçak M, Büyükkaragöz B, Can $Y$, et al. The Epidemiological, Clinical and Laboratory Features of 91 Children with Henoch-Schönlein Purpura. Abant Medical Journal. 2015; 4: 134-40.

23. Cakiter AU, Kucuk OS, Ozkaya DB, Topukcu B, Onsun N. Demographic characteristics, aetiology, and assessment of treatment options in leukocytoclastic vasculitis. Postepy Dermatol Alergol. 2017; 34: 104-9.

24. Ekinci RMK, Balci S, Melek E, et al. Clinical manifestations and outcomes of 420 children with Henoch Schönlein Purpura from a single referral center from Turkey: A three-year experience. Mod Rheumatol. 2020; 30: 1039-46.

25. Buyan N, Erbaş D, Akkök N, et al. Role of free oxygen radicals and prostanoids in the pathogenesis of Henoch-Schönlein Purpura. Prostaglandins Leukot Essent Fatty Acids. 1998; 59: 181-4.

26. Erdoğan 0, Oner A, Aydin A, et al. Effect of vitamin $\mathrm{E}$ treatment on the oxidative damage occurring in Henoch-Schönlein purpura. Acta Paediatr. 2003; 92: 546-50.

27. Ece A, Kelekçi S, Kocamaz H, et al. Antioxidant enzyme activities, lipid peroxidation, and total antioxidant status in children with HenochSchönlein purpura. Clin Rheumatol. 2008; 27: 16369.

28. Gurses D, Parlaz N, Bor Kucukatay M, et al. Evaluation of oxidative stress and erythrocyte properties in children with henoch-shoenlein purpura. Iran J Pediatr. 2014; 24: 166-72. 